\title{
Remote Detection of Rhizomania in Sugar Beets
}

\author{
K. Steddom, G. Heidel, D. Jones, and C. M. Rush
}

Texas Agricultural Experiment Station, 6500 Amarillo Boulevard West, Amarillo, Texas 79016-1796.

Accepted for publication 23 January 2003.

\section{ABSTRACT}

Steddom, K., Heidel, G., Jones, D., and Rush, C. M. 2003. Remote detection of rhizomania in sugar beets. Phytopathology 93:720-726.

As a prelude to remote sensing of rhizomania, hyper-spectral leaf reflectance and multi-spectral canopy reflectance were used to study the physiological differences between healthy sugar beets and beets infested with Beet necrotic yellow vein virus. This study was conducted over time in the presence of declining nitrogen levels. Total leaf nitrogen was significantly lower in symptomatic beets than in healthy beets. Chlorophyll and carotenoid levels were reduced in symptomatic beets. Vegetative indices calculated from leaf spectra showed reductions in chlorophyll and carotenoids in symptomatic beets. Betacyanin levels estimated from leaf spectra were decreased at the end of the 2000 season and not in 2001. The ratio of betacyanins to chlorophyll, estimated from canopy spectra, was increased in symptomatic beets at four of seven sampling dates. Differences in betacyanin and carotenoid levels appeared to be related to disease and not nitrogen content. Vegetative indices calculated from multi-spectral canopy spectra supported results from leaf spectra. Logistic regression models that incorporate vegetative indices and reflectance correctly predicted $88.8 \%$ of the observations from leaf spectra and $87.9 \%$ of the observations for canopy reflectance into healthy or symptomatic classes. Classification was best in August with a gradual decrease in accuracy until harvest. These results indicate that remote sensing technologies can facilitate detection of rhizomania.

Additional keywords: anthocyanin ratio index, Beta vulgaris, carotenoid reflectance index, normalized difference vegetative index, radiometry.
Rhizomania is a viral disease of sugar beets (Beta vulgaris L.) caused by Beet necrotic yellow vein virus (BNYVV). BNYVV is vectored by the zoosporic fungus, Polymyxa betae, Keskin (38) and causes a proliferation of roots, yellowing of the foliage, and a reduction in extractable sucrose $(38,43)$. BNYVV appears to interfere with nitrogen assimilation resulting in reduced chlorophyll content and chlorosis $(9,30,35)$. In healthy beets, there is an inverse relationship between nitrogen and extractible sucrose concentration $(10,44)$. To maximize sugar production in sugar beets, growers manage nitrogen to allow a deficiency to occur 4 to 6 weeks prior to harvest (44). Symptoms of rhizomania and nitrogen depletion appear similar and can be difficult to distinguish. However, those plants with rhizomania will have low extractable sucrose while healthy plants with low nitrogen will have high levels of extractable sucrose. This dichotomy makes it difficult to assess potential yield in areas where rhizomania exists.

Remote sensing is frequently used for simultaneous, nondestructive estimation of important agronomic factors such as pigment concentrations and canopy density over large areas at relatively low cost $(19,22,32,45)$. Knowledge of the spatial distribution of theses factors provides an important tool for management strategies such as integrated pest management and sitespecific management. The reflectance of leaves in the visible regions of the spectrum is controlled by pigment concentrations, while reflectance in the near infrared up to $1,000 \mathrm{~nm}$ is controlled by leaf structure (26). Vegetative indices use reflectance at different areas of the spectrum to quantify specific parameters and are more robust than the use of individual wavelengths (8). Several vegetative indices have been proposed for the remote sensing of plant pigments and canopy coverage (14-18). Other studies have demonstrated the usefulness of remote sensing for detecting biomass $(1,3,4)$, nutrient deficiencies $(5,12,27,29,39)$, insect infesta-

Corresponding author: K. Steddom; E-mail address: K-Steddom@tamu.edu

Publication no. P-2003-0410-01R

(C) 2003 The American Phytopathological Society tions (37), and plant pathogens $(6,13,23,31,33,34,36)$. The impact of plant pathogens on plant pigments has been well studied in the past $(2,7,11,28,40,47)$. Remote sensing of plant diseases through the quantification of canopy coverage and pigment concentrations would allow rapid assessment of disease incidence and resulting yield losses.

The objectives of this study were to quantify the impact of rhizomania on leaf physiology and leaf and canopy reflectance during the natural decline in nitrogen that occurs at the end of the sugar beet growing season.

\section{MATERIALS AND METHODS}

Field selection and sampling. In the 2000 growing season, three fields east of Fargo, ND $\left(47^{\circ} 00^{\prime} \mathrm{N}, 96^{\circ} 38^{\prime} \mathrm{W}\right)$ and four fields west of Willmar, MN $\left(45^{\circ} 05^{\prime} \mathrm{N}, 95^{\circ} 29^{\prime} \mathrm{W}\right)$ were selected. The study was repeated in the 2001 growing season with three fields east of Fargo and three fields west of Willmar. Fields were selected that showed discrete yellow patches with root symptoms characteristic of rhizomania and nearby regions that appeared healthy with dark green foliage and no root symptoms of rhizomania. In each field, a large symptomatic area and a near-by healthy-appearing area were selected. This paired sampling strategy was selected to minimize the impact of varying soil fertility and cultural practices. These areas were sampled on 7 and 22 August, 20 September, and 5 October in 2000 and on 14 and 31 August, and 28 September in 2001. The initial dates correspond to the onset of rhizomania symptoms, and the final dates correspond to approximately 1 week before harvest. As the season progressed, healthy beets were observed to grow more yellow until differentiation of the diseased spots was difficult near harvest, with 2000 showing more yellowing than 2001. At each sampling date, four areas of uniform beet canopy were randomly selected from each plot. When weather permitted, canopy reflectance was measured. The beet in the center and directly below the radiometer was removed for collection of leaves and feeder roots. This gave a total of eight samples per field. Four to six leaves and several 
grams of feeder root tissue from the lateral groove of the taproot were collected from each plant, placed in sealed plastic bags, and transported back to the lab.

Canopy reflectance. Canopy reflectance from healthy and diseased spots was measured with a Crop Scan Multispectral Field Radiometer version MSR16 (CropScan, Inc., Rochester, MN). This is a multi-spectral radiometer that measures solar light intensity and canopy reflected light intensity simultaneously in nine fixed wavebands. The bands have the following characteristics: band $1=458.7 \mathrm{~nm}$ center wavelength (cw) and $7 \mathrm{~nm}$ wide; band $2=509.8 \mathrm{~nm} \mathrm{cw}$ and $8 \mathrm{~nm}$ wide; band $3=559 \mathrm{~nm} \mathrm{cw}$ and $9 \mathrm{~nm}$ wide; band $4=611.9 \mathrm{~nm} \mathrm{cw}$ and $10 \mathrm{~nm}$ wide; band $5=660.1 \mathrm{~nm}$ $\mathrm{cw}$ and $11 \mathrm{~nm}$ wide; band $6=708.3 \mathrm{~nm} \mathrm{cw}$ and $12 \mathrm{~nm}$ wide; band $7=760.4 \mathrm{~nm} \mathrm{cw}$ and $28 \mathrm{~nm}$ wide; band $8=813.2 \mathrm{~nm} \mathrm{cw}$ and $32 \mathrm{~nm}$ wide; and band $9=935.0 \mathrm{~nm} \mathrm{cw}$ and $290 \mathrm{~nm}$ wide. Software that accompanies the radiometer divides the canopy reflected light intensity by the solar light intensity to provide percent reflectance for each waveband. The sensor has a $28^{\circ}$ field of view and was set at approximately $1.5 \mathrm{~m}$ above the canopy perpendicular to the ground giving a $0.75 \mathrm{~m}$ diameter field of view. Each beet canopy was approximately $50 \mathrm{~cm}$ wide. Due to the large field of view, the canopy from neighboring plants was included in the readings, but reflectance from soil was minimal. The $50-\mathrm{cm}$ row spacing used in this region resulted in a dense canopy with good closure at the initiation of sampling. Readings were taken between 10 am and $2 \mathrm{pm}$ under sunny conditions with a sun angle between $29^{\circ}$ and $69^{\circ}$. Reflectance data was used to calculate vegetative indices given in Table 1.

Sample processing. The presence of BNYVV was assayed by enzyme-linked immunosorbent assay (ELISA) on feeder root tissue from the lateral groove of the taproot as previously described (20). Leaf samples were cut into $4 \mathrm{~cm}$ wide strips and one piece was randomly selected from each sample for gathering individual leaf reflectance as described below. All samples were processed within $24 \mathrm{~h}$ of field collection and frozen at $-20^{\circ} \mathrm{C}$ until pigments were extracted.

Individual leaf reflectance. Reflectance of intact, individual leaves from the field samples was measured with a hyper-spectral
ASD FieldSpec FR radiometer (Analytical Spectral Devices, Inc. Boulder, CO) attached to a Li-Cor Li-1800-12 integrating sphere (Li-Cor, Inc., Lincoln, NB). The integrating sphere provided a controlled sampling environment with uniform lighting and hemispherical reflectance, which is desirable for solid samples. The ASD radiometer was configured to read from $350 \mathrm{~nm}$ to $1,000 \mathrm{~nm}$ in $1 \mathrm{~nm}$ increments. Irradiance for dark readings, a packed barium sulfate standard, and upper leaf surface reflectance were measured. Each reading was the result of 5 replicate subsamples that were averaged. The sampling port of the integrating sphere was $1 \mathrm{~cm}$ in diameter, and leaves were positioned in the sampling port to avoid major central leaf veins. Reflectance was calculated as (Reflected Irradiance-Dark Irradiance)/(Barium Sulfate Irradiance) in S-Plus 6.1 for Windows (Insightful, Inc., Seattle, WA). Vegetative indices were calculated with the formulas given in Table 1.

Vegetative indices. Vegetative indices were selected for their ability to quantify specific pigments (Table 1). The normalized difference vegetative index (NDVI) has been used in many studies to quantify chlorophyll concentration and photosynthetically active leaf area while being resistant to the effects of shadowing (8). The formula presented here has been adjusted to be more specific to chlorophyll concentration (14). The visible atmospherically resistant index (VARI) quantifies the amount of green vegetation present in the field of view of the radiometer (15). The red green ratio (RGR) estimates the ratio of red pigments to chlorophylls with higher values indicating higher levels of red pigments relative to chlorophyll content (14). The anthocyanin ratio index (ARI) quantifies red pigments such as anthocyanins and betacyanins in the presence of variable levels of chlorophyll, providing pigment content independent of chlorophyll (17; A. A. Gitelson, personal communication). The carotenoid reflectance index (CRI) quantifies carotenoid content in leaves (18). Due to the positions of the wide band-pass filters used in the CropScan radiometer, ARI and CRI could not be calculated for canopy reflectance. Since VARI quantifies canopy coverage, it was not appropriate to calculate this for leaf reflectance. All of these measures are unit-less and represent the relative concentrations of pigments.

TABLE 1. Vegetative indices calculated for canopy and leaf reflectance of sugar beets

\begin{tabular}{llcc}
\hline Vegetative index & Description & Leaf reflectance formula $^{\mathrm{y}}$ & Canopy reflectance formula $^{\mathrm{z}}$ \\
\hline Normalized difference vegetative index (NDVI) & Chlorophyll & $\frac{(R 745: 755-R 700: 710)}{(R 745: 755+R 700: 710)}$ & $\frac{(R 760.4-R 708.3)}{(R 760.4+R 708.3)}$ \\
Visible atmospherically resistant index (VARI) & Canopy coverage & NA & $\frac{(R 559.7-R 660.1)}{(R 559.7+R 660.1-R 458.7)}$ \\
Red green ratio (RGR) & Red pigments/chlorophyll & $\frac{(R 600: 699)}{(R 500: 599)}$ & $\frac{(R 611.9+R 660.1)}{(R 509.8+R 559.7)}$ \\
Anthocyanin ratio index (ARI) & Red pigments & $\frac{1}{R 550: 551}-\frac{1}{R 700: 701}$ & NA \\
Carotenoid reflectance index (CRI) & Carotenoid & $\frac{1}{R 505: 515}-\frac{1}{R 535: 565}$ & NA
\end{tabular}

${ }^{\mathrm{y}} R_{745: 755}$ is the average reflectance between $745 \mathrm{~nm}$ and $755 \mathrm{~nm}$ as measured by the ASD FieldSpec FR and the Li-Cor integrating sphere.

${ }^{\mathrm{z}} R_{760.4}$ is the reflectance recorded by the sensor with a center wavelength of $760.4 \mathrm{~nm}$ in the CropScan MSR 16 multi-spectral radiometer.

TABLE 2. Leaf nutrient analysis of sugar beets from the first and last sample dates of 2001 from fields in Willmar, MN and Fargo, ND ${ }^{x y}$

\begin{tabular}{|c|c|c|c|c|c|c|c|c|c|c|}
\hline Disease level $^{\mathrm{z}}$ & $\mathrm{N}(\%)$ & $\mathrm{Na}(\mathrm{ppm})$ & $\mathrm{P}(\mathrm{ppm})$ & $\mathrm{K}(\mathrm{ppm})$ & $\mathrm{Ca}(\mathrm{ppm})$ & Mn (ppm) & $\mathrm{Fe}(\mathrm{ppm})$ & $\mathrm{Cu}(\mathrm{ppm})$ & $\mathrm{Zn}(\mathrm{ppm})$ & $\mathrm{Mg}(\mathrm{ppm})$ \\
\hline Healthy & $4.11 \mathrm{a}$ & $26089 a$ & $2600 a$ & $27944 \mathrm{~b}$ & $10200 \mathrm{~b}$ & $84.5 \mathrm{~b}$ & $147.6 \mathrm{a}$ & $15.2 \mathrm{a}$ & $34.2 \mathrm{~b}$ & 9944 b \\
\hline Symptomatic & $2.95 \mathrm{~b}$ & $24263 \mathrm{a}$ & $2518 \mathrm{a}$ & $31294 \mathrm{a}$ & $15505 \mathrm{a}$ & $243.7 \mathrm{a}$ & $106.2 \mathrm{~b}$ & $15.6 \mathrm{a}$ & $48.1 \mathrm{a}$ & $12639 a$ \\
\hline
\end{tabular}

${ }^{\mathrm{x}}$ Data from the two dates and both regions were similar and therefore combined.

${ }^{y}$ Means followed by the same letter within a column were not significantly different $(P>0.05)$ according to multiple orthogonal contrasts.

${ }^{z}$ Disease level was healthy if the beet came from a healthy appearing area and tested negative for Beet necrotic yellow vein virus (BNYVV), asymptomatic if the beet came from a healthy appearing area and tested positive for BNYVV, and symptomatic if the beet came from an area with symptoms of BNYVV. 
Pigment extractions. Following leaf spectra acquisition, samples were frozen at $-20^{\circ} \mathrm{C}$ until leaf pigments were extracted. Frozen leaves were crushed by hand, mixed, and $0.5 \mathrm{~g}$ of leaf tissue from between the major veins was placed into a screw cap microfuge tube with approximately $1 \mathrm{~g}$ of $2.5 \mathrm{~mm}$ zirconia/silica beads (BioSpec, Inc., Bartlesville, OK). To each sample, $1 \mathrm{ml}$ of cold acetone was added, and the samples homogenized in a Bio 101 Fast Prep FP120 (Qbiogene, Carlsbad, CA) at setting 6 for $20 \mathrm{~s}$. Tubes were placed in a micro-centrifuge and spun briefly to clear the extract. From each sample, $100 \mu \mathrm{l}$ of acetone with the extracted pigments was removed, added to $0.9 \mathrm{ml}$ of cold acetone, and placed in a spectrophotometer cell. Pigment concentrations for total chlorophyll and carotenoids were calculated from the formulas given in Lichtenthaler (24) for 100\% acetone extracts.

Leaf nutrient analysis. Following leaf pigment extraction, leaf samples were dried at $45^{\circ} \mathrm{C}$. Samples from two fields in the Fargo, ND area and 2 fields from the Willmar, MN area from the first and last sampling dates in 2001 were sent to the Texas A\&M Soil, Water, and Forage Testing Laboratory, College Station. Samples were analyzed for total nitrogen, sodium, phosphorus, potassium, calcium, manganese, iron, copper, zinc, and magnesium.

Data management and analysis. Each observation from a single plant was classified as healthy, symptomatic, or asymptomatic on the basis of ELISA results, and whether the sample came from a yellow area or from a green area. Asymptomatic beets came from a healthy area of the field and did not display characteristic symptoms of BNYVV but tested positive for BNYVV using ELISA. The number of asymptomatic beets detected varied by field and sampling date with asymptomatic beets more prevalent in the Willmar area, however, results were similar between the disease levels from fields in both regions. Data between regions was combined to simplify presentation of results. One

TABLE 3. Average quantities of chlorophylls and carotenoids extracted from sugar beet leaf tissue for all fields ${ }^{x y}$

\begin{tabular}{|c|c|c|c|c|}
\hline Year & $\begin{array}{l}\text { Sampling } \\
\text { date }\end{array}$ & Disease level $^{z}$ & $\begin{array}{c}\text { Total } \\
\text { chlorophylls } \\
\text { ( } \mu \mathrm{g} / \text { gram of } \\
\text { leaf tissue) }\end{array}$ & $\begin{array}{c}\text { Total } \\
\text { carotenoids } \\
\text { ( } \mu \mathrm{g} / \text { gram of } \\
\text { leaf tissue) }\end{array}$ \\
\hline \multicolumn{5}{|l|}{2000} \\
\hline & \multirow[t]{3}{*}{7 August } & Healthy & $482.5 \mathrm{a}$ & $80.0 \mathrm{a}$ \\
\hline & & Asymptomatic & $414.7 \mathrm{a}$ & $54.0 \mathrm{ab}$ \\
\hline & & Symptomatic & $177.4 \mathrm{~b}$ & $41.2 \mathrm{~b}$ \\
\hline & \multirow[t]{3}{*}{22 August } & Healthy & $624.7 \mathrm{a}$ & $91.6 \mathrm{a}$ \\
\hline & & Asymptomatic & $599.0 \mathrm{a}$ & $84.6 \mathrm{a}$ \\
\hline & & Symptomatic & $286.0 \mathrm{~b}$ & $69.9 \mathrm{a}$ \\
\hline & \multirow[t]{3}{*}{20 September } & Healthy & $439.0 \mathrm{~b}$ & $90.1 \mathrm{a}$ \\
\hline & & Asymptomatic & $598.5 \mathrm{a}$ & $105.7 \mathrm{a}$ \\
\hline & & Symptomatic & $283.4 \mathrm{c}$ & $75.9 \mathrm{~b}$ \\
\hline & \multirow[t]{3}{*}{5 October } & Healthy & $534.9 \mathrm{a}$ & $100.1 \mathrm{a}$ \\
\hline & & Asymptomatic & $848.6 \mathrm{a}$ & $125.4 \mathrm{a}$ \\
\hline \multirow{2}{*}{\multicolumn{5}{|c|}{ 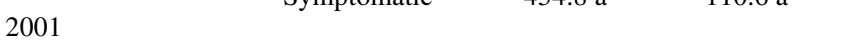 }} \\
\hline & & & & \\
\hline & \multirow[t]{3}{*}{14 August } & Healthy & $654.3 \mathrm{a}$ & $104.6 \mathrm{a}$ \\
\hline & & Asymptomatic & $568.0 \mathrm{ab}$ & $136.9 \mathrm{a}$ \\
\hline & & Symptomatic & $361.3 \mathrm{~b}$ & $86.4 \mathrm{~b}$ \\
\hline & \multirow[t]{3}{*}{31 August } & Healthy & $662.6 \mathrm{a}$ & $108.7 \mathrm{a}$ \\
\hline & & Asymptomatic & $869.7 \mathrm{a}$ & $121.3 \mathrm{a}$ \\
\hline & & Symptomatic & $358.8 \mathrm{~b}$ & $76.0 \mathrm{~b}$ \\
\hline & \multirow[t]{3}{*}{28 September } & Healthy & $683.8 \mathrm{a}$ & $122.3 \mathrm{a}$ \\
\hline & & Asymptomatic & $755.8 \mathrm{ab}$ & $111.7 \mathrm{a}$ \\
\hline & & Symptomatic & $553.0 \mathrm{~b}$ & $107.8 \mathrm{a}$ \\
\hline
\end{tabular}

\footnotetext{
${ }^{\mathrm{x}}$ Data from both regions were similar and therefore combined.
}

${ }^{y}$ Means within a column and a single sampling date followed by the same letters are not significantly different according to multiple orthogonal contrasts $(P>0.05)$.

${ }^{\mathrm{z}}$ Disease level was healthy if the beet came from a healthy appearing area and tested negative for Beet necrotic yellow vein virus (BNYVV), asymptomatic if the beet came from a healthy appearing area and tested positive for BNYVV, and symptomatic if the beet came from an area with symptoms of BNYVV. field from the Willmar region in 2001 had a low percentage of beets testing positive for BNYVV so all observations from this field were excluded from the data set.

Analysis of variance (SAS Institute Inc., Cary, NC) was used to compare disease levels (healthy, asymptomatic, and symptomatic) for leaf nutrient content, vegetative indices from canopy and leaf reflectance, and pigment concentrations. The variable levels of asymptomatic samples resulted in unequal cell sizes. Due to this, disease level means were separated with multiple orthogonal contrasts, except for canopy reflectance, which lacked the degrees of freedom for this approach. Canopy reflectance disease level means were separated with Fisher's protected least significance difference (LSD) test $(\alpha<0.05)$. Chlorophyll is highly correlated other plant pigments (41). To assess the independence of carotenoids and betacyanins from chlorophyll, NDVI for leaf reflectance was used as a covariate in analysis of variance. To study the impact of varying levels of nitrogen in healthy plants, leaf nitrogen content was regressed on pigment concentrations and vegetative indices from canopy and leaf reflectance. Stepwise logistic regression analysis was used to build models predicting disease from canopy reflectance and vegetative indices or leaf reflectance and vegetative indices. The stepwise selection procedure was preferred over other selection methods due to the large number of potential variables available for each model. A liberal model entry value of 0.25 was selected to evaluate a large number of variables, while a conservative value of 0.05 was used to select variables to keep in the model. Hosmer and Lemeshow (21) recommended this approach where the purpose of the analysis is to screen a large number of potential variables for inclusion in a model.

\section{RESULTS}

Leaf nutrients. Results between the two sampling dates were similar, therefore the data was combined and presented together (Table 2). Significant differences between healthy and symptomatic beets existed for nitrogen, potassium, calcium, manganese, iron, zinc, and magnesium. Asymptomatic beets were not different from healthy beets for any nutrient. All of the nutrients fell within the normal range of acceptable levels except for nitrogen, potassium, calcium, iron, and magnesium (44). Normal leaf nitrogen levels for sugar beets range between 3.0 and 6.0\% (44). Symptomatic beets were just below the lower limit at $2.95 \%$. Potassium and calcium were both deficient for all disease levels (44). Iron in healthy and asymptomatic beet leaves was slightly higher than the maximum normal value of $140 \mathrm{ppm}$ (44). Magnesium in healthy

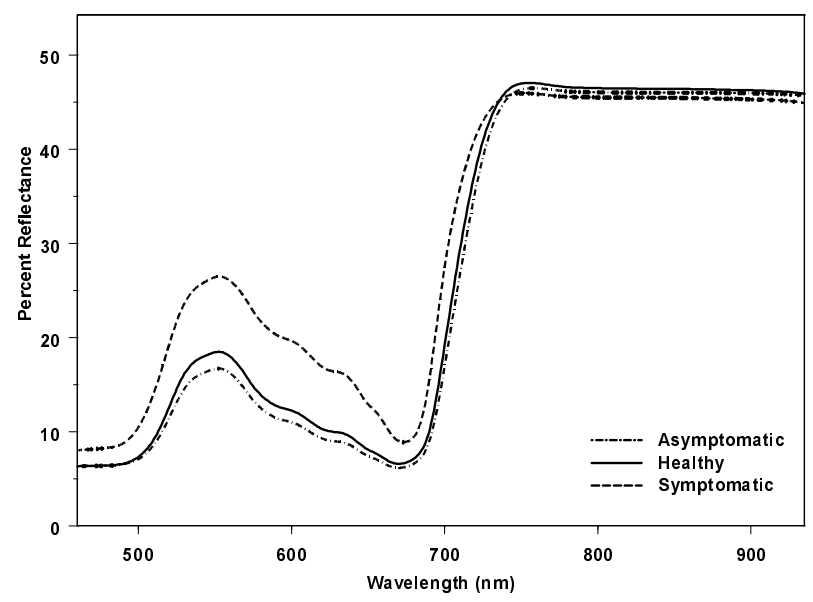

Fig. 1. Averaged spectra from leaf level reflectance for healthy sugar beets and beets symptomatic and asymptomatic for Beet necrotic yellow vein virus for 7 August 2000 samples from fields in Fargo, ND and Willmar, MN. This is from a hyper-spectral radiometer with a $1 \mathrm{~nm}$ spectral resolution. 
beets was slightly below the minimum of $0.10 \%$ (44). The elevated levels of iron may be due to the deficiencies of potassium and calcium (44).

Leaf pigment concentrations. Chlorophyll levels were consistently lower in symptomatic leaves than healthy or asymptomatic leaves (Table 3). Differences were significant at all sample dates except for the final sampling date of 2000. Chlorophyll levels in asymptomatic leaves were not significantly different from healthy leaves at any time except for the third sampling date in 2000 when asymptomatic leaves had higher levels of chlorophyll than healthy leaves. Carotenoid levels showed greater variation than chlorophyll levels (Table 3). Carotenoid levels were consistently lower in symptomatic leaves than healthy and asymptomatic leaves except for the fourth sampling date in 2000 when differences were not significant. When leaf nitrogen was regressed on chlorophyll and carotenoid concentrations, only chlorophyll showed a significant effect $(P<0.0001)$ but only a small portion of the variation was explained $\left(R^{2}=0.53\right)$.

Leaf reflectance vegetative indices. Spectra from leaf reflectance showed greater reflectance in the visible region $(400 \mathrm{~nm}$ to $700 \mathrm{~nm}$ ) for symptomatic beets than healthy or asymptomatic and nearly the same reflectance for all in the near infrared region (700 $\mathrm{nm}$ to $1,000 \mathrm{~nm}$ ) (Fig. 1). NDVI values for leaf reflectance were consistently and significantly lower in symptomatic leaves than healthy or asymptomatic leaves indicating reduced levels of chlorophyll (Table 4). Asymptomatic leaves consistently had higher NDVI values than healthy leaves but the differences were never significant. CRI values were consistently and significantly lower in symptomatic leaves than in healthy or asymptomatic leaves except for the third sampling date of 2000, suggesting lower concentrations of carotenoids. RGR levels for symptomatic leaves were significantly higher in the first three sampling dates of 2000 but not on the fourth sampling date or any of the sampling dates in 2001. This indicates higher concentrations of betacyanins relative to chlorophyll in symptomatic beets. However, ARI showed a significant decrease in betacyanin content independent of chlorophyll content in symptomatic leaves only in the final two sampling dates of 2000 and never in 2001. The greatest separation between disease levels, as measured by the AOV $F$ statistic, was in August for NDVI, CRI, and RGR and in September for ARI. When leaf nitrogen content was regressed on these vegetative indices, only ARI showed a significant relationship $(P=0.04)$ that was very small $\left(R^{2}=0.12\right)$.

Canopy reflectance vegetative indices. Canopy reflectance showed similar results for healthy, symptomatic, and asymptomatic beets throughout the spectral range of the multi-spectral radiometer (Fig. 2). NDVI calculated for canopy reflectance was significantly lower in symptomatic plants than healthy or asymptomatic plants (Table 5) indicating reduced chlorophyll content. VARI, a measure of photosynthetic canopy area, was also significantly lower in symptomatic plants than healthy or asymptomatic plants except for the final sampling date of 2000 and the second

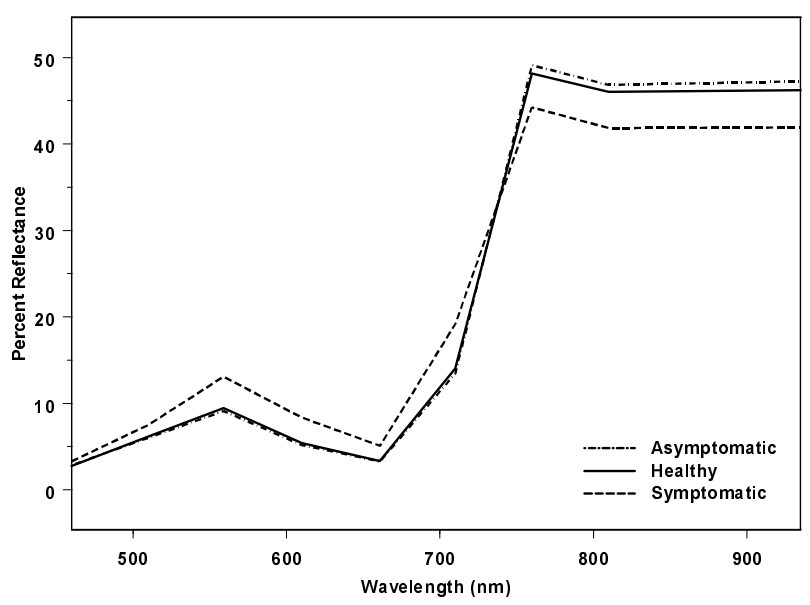

Fig. 2. Averaged spectra from canopy level reflectance for healthy sugar beets and beets symptomatic and asymptomatic for Beet necrotic yellow vein virus for 7 August 2000 samples from fields in Fargo, ND and Willmar, MN. This is from a 9 band multi-spectral radiometer.

TABLE 4. Average values for vegetative indices from leaf reflectance for all fields ${ }^{\mathrm{wx}}$

\begin{tabular}{|c|c|c|c|c|c|c|}
\hline Year & Sampling date & Disease level ${ }^{\mathrm{y}}$ & $\mathrm{NDVI}^{\mathrm{Z}}$ & $\mathrm{CRI}^{\mathrm{z}}$ & $\mathrm{RGR}^{\mathrm{z}}$ & $\mathrm{ARI}^{\mathrm{z}}$ \\
\hline \multicolumn{7}{|l|}{2000} \\
\hline & \multirow[t]{3}{*}{7 August } & Healthy & $0.35 \mathrm{a}$ & $5.63 \mathrm{a}$ & $0.64 \mathrm{~b}$ & $0.22 \mathrm{a}$ \\
\hline & & Asymptomatic & $0.36 \mathrm{a}$ & $5.58 \mathrm{a}$ & $0.66 \mathrm{~b}$ & $0.31 \mathrm{a}$ \\
\hline & & Symptomatic & $0.12 \mathrm{~b}$ & $2.58 \mathrm{~b}$ & $0.73 \mathrm{a}$ & $0.20 \mathrm{a}$ \\
\hline & \multirow[t]{3}{*}{22 August } & Healthy & $0.32 \mathrm{a}$ & $5.25 \mathrm{a}$ & $0.65 \mathrm{~b}$ & $0.35 \mathrm{a}$ \\
\hline & & Asymptomatic & $0.36 \mathrm{a}$ & $5.43 \mathrm{a}$ & $0.65 \mathrm{~b}$ & $0.26 \mathrm{a}$ \\
\hline & & Symptomatic & $0.18 \mathrm{~b}$ & $3.35 \mathrm{~b}$ & $0.68 \mathrm{a}$ & $0.21 \mathrm{a}$ \\
\hline & \multirow[t]{3}{*}{20 September } & Healthy & $0.31 \mathrm{a}$ & $5.07 \mathrm{~b}$ & $0.66 \mathrm{a}$ & $0.40 \mathrm{a}$ \\
\hline & & Asymptomatic & $0.32 \mathrm{a}$ & $5.19 \mathrm{a}$ & $0.67 \mathrm{a}$ & $0.30 \mathrm{ab}$ \\
\hline & & Symptomatic & $0.18 \mathrm{~b}$ & $3.42 \mathrm{c}$ & $0.69 \mathrm{a}$ & $0.22 \mathrm{~b}$ \\
\hline & \multirow[t]{3}{*}{5 October } & Healthy & $0.28 \mathrm{a}$ & $5.04 \mathrm{a}$ & $0.69 \mathrm{a}$ & $0.58 \mathrm{a}$ \\
\hline & & Asymptomatic & $0.30 \mathrm{a}$ & $5.25 \mathrm{a}$ & $0.68 \mathrm{a}$ & $0.46 \mathrm{ab}$ \\
\hline & & Symptomatic & $0.18 \mathrm{~b}$ & $3.67 \mathrm{~b}$ & $0.69 \mathrm{a}$ & $0.28 \mathrm{~b}$ \\
\hline \multicolumn{7}{|l|}{2001} \\
\hline & \multirow[t]{3}{*}{14 August } & Healthy & $0.34 \mathrm{a}$ & $5.35 \mathrm{a}$ & $0.66 \mathrm{a}$ & $0.39 \mathrm{a}$ \\
\hline & & Asymptomatic & $0.37 \mathrm{a}$ & $5.59 \mathrm{ab}$ & $0.68 \mathrm{a}$ & $0.26 \mathrm{a}$ \\
\hline & & Symptomatic & $0.23 \mathrm{~b}$ & $3.97 \mathrm{~b}$ & $0.67 \mathrm{a}$ & $0.28 \mathrm{a}$ \\
\hline & \multirow[t]{3}{*}{31 August } & Healthy & $0.35 \mathrm{a}$ & $4.95 \mathrm{a}$ & $0.67 \mathrm{a}$ & $0.34 \mathrm{ab}$ \\
\hline & & Asymptomatic & $0.36 \mathrm{a}$ & $5.08 \mathrm{ab}$ & $0.68 \mathrm{a}$ & $0.53 \mathrm{a}$ \\
\hline & & Symptomatic & $0.22 \mathrm{~b}$ & $3.83 \mathrm{~b}$ & $0.67 \mathrm{a}$ & $0.21 \mathrm{~b}$ \\
\hline & \multirow[t]{3}{*}{28 September } & Healthy & $0.33 \mathrm{a}$ & $5.22 \mathrm{a}$ & $0.66 \mathrm{a}$ & $0.38 \mathrm{a}$ \\
\hline & & Asymptomatic & $0.35 \mathrm{ab}$ & $6.65 \mathrm{a}$ & $0.65 \mathrm{a}$ & $0.88 \mathrm{a}$ \\
\hline & & Symptomatic & $0.25 \mathrm{~b}$ & $4.31 \mathrm{~b}$ & $0.66 \mathrm{a}$ & $0.37 \mathrm{a}$ \\
\hline
\end{tabular}

${ }^{\mathrm{w}}$ Data from both regions were similar and therefore combined.

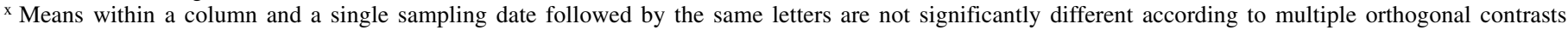
$(P>0.05)$.

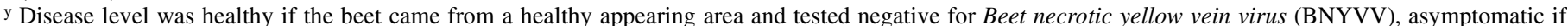
the beet came from a healthy appearing area and tested positive for BNYVV, and symptomatic if the beet came from an area with symptoms of BNYVV.

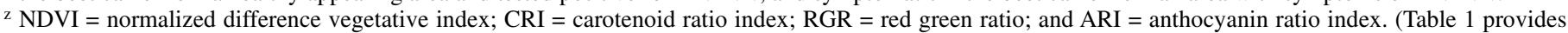
formulas). 
TABLE 5. Canopy reflectance vegetative indices of sugar beets ${ }^{\mathrm{vw}}$

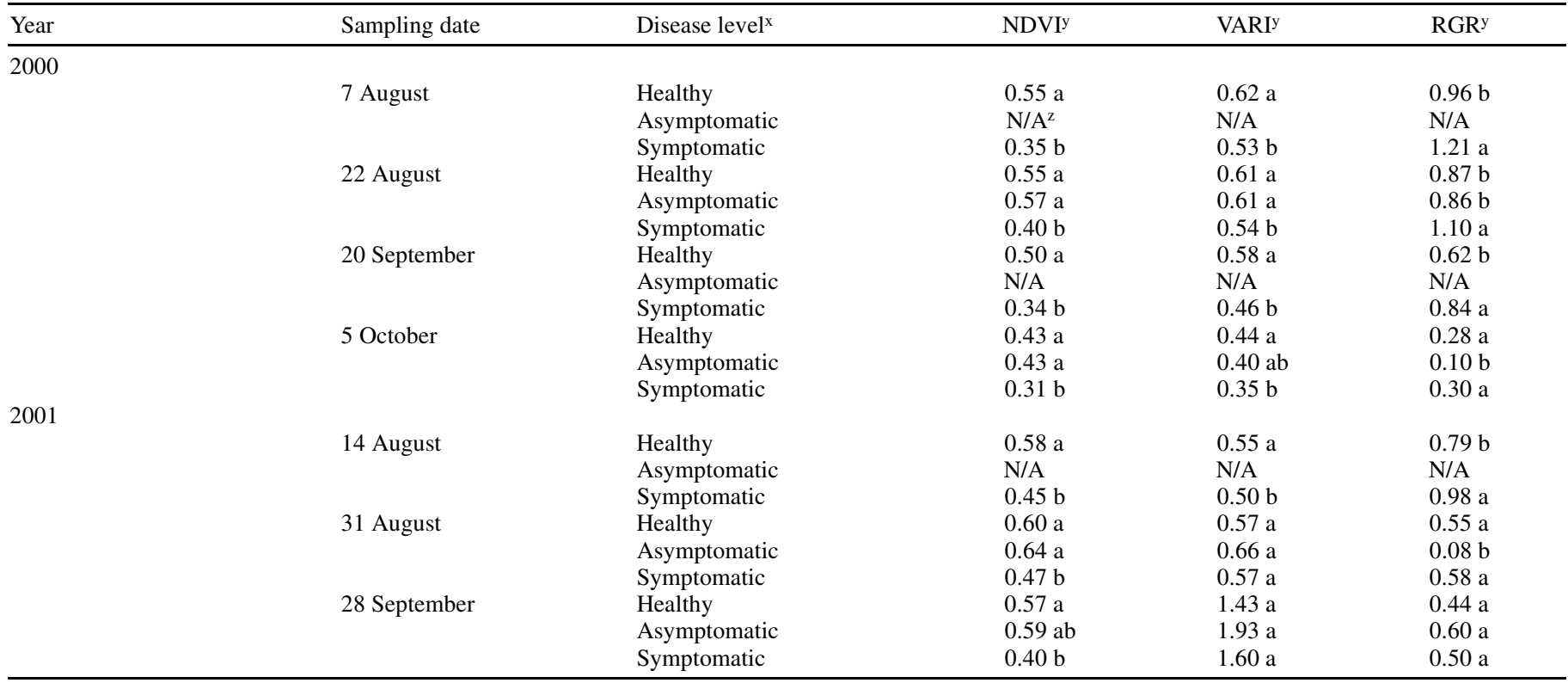

${ }^{\mathrm{v}}$ Data from both regions were similar and therefore combined.

" Means within a column and a single sampling date followed by the same letters are not significantly different according to Fisher's protected LSD test $(\alpha<0.05)$.

${ }^{\mathrm{x}}$ Disease level was healthy if the beet came from a healthy appearing area and tested negative for Beet necrotic yellow vein virus (BNYVV), asymptomatic if the beet came from a healthy appearing area and tested positive for BNYVV, and symptomatic if the beet came from an area with symptoms of BNYVV.

y NDVI = normalized difference vegetative index; VARI = visible atmospherically resistant index; and RGR $=$ red green ratio. Table 1 provides formulas.

${ }^{\mathrm{z}} \mathrm{NA}=$ Asymptomatic beets were not detected at this time. Canopy reflectance was not measured in some fields due to weather conditions.

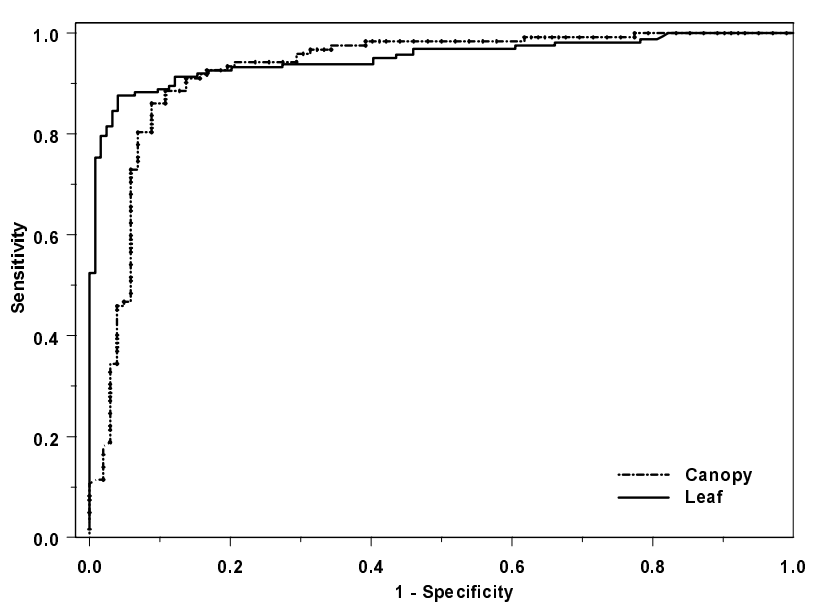

Fig. 3. Receiver operator curve for leaf and canopy reflectance logistic regression models for 2000 and 2001 data from fields in Fargo, ND and Willmar, MN.

and third sampling dates of 2001. Since VARI is based on the greenness of the canopy, this probably reflects reduced chlorophyll content and not reduced leaf area. RGR was significantly higher in symptomatic plants than healthy or asymptomatic plants except for the second and third sampling dates of 2001. This indicates a higher ratio of betacyanins to chlorophyll in symptomatic plants. RGR also had a significant regression to leaf nitrogen $(P=0.01)$ with a very small relationship $\left(R^{2}=0.26\right)$.

Logistic regression. Ordinal stepwise logistic regression was performed on leaf reflectance and vegetative indices for healthy, asymptomatic, and symptomatic samples. Asymptomatic samples could not reliably be separated from healthy observations with the maximum probability of a sample being classified as asymptomatic only reaching 0.25 . This was not surprising, as leaf pigments and leaf and canopy vegetative indices indicated little
TABLE 6. Percentage of observations from specific sampling dates and locations that were correctly classified by the leaf reflectance logistic regression model $^{\mathrm{z}}$

\begin{tabular}{llrr}
\hline Year & Sampling date & Fargo, ND & Willmar, MN \\
\hline 2000 & & & \\
& 7 August & 95.8 & 100.0 \\
& 22 August & 90.0 & 100.0 \\
& 20 September & 100.0 & 87.0 \\
& 5 October & 70.8 & 92.3 \\
& & & \\
& 14 August & 100.0 & 71.4 \\
& 31 August & 91.7 & 66.7 \\
& 28 September & 95.8 & 60.0 \\
\hline
\end{tabular}

${ }_{\mathrm{z}}$ Asymptomatic beets were excluded from this analysis.

difference between healthy and asymptomatic beets. Asymptomatic observations were removed from the data set, and binomial stepwise logistic regression was performed on leaf reflectance and vegetative indices and canopy reflectance and vegetative indices to predict symptomatic samples. Canopy reflectance was able to predict the correct disease level of $87.9 \%$ of the observations using a cutoff of 0.46 with the model of 0.03 (reflectance at a center wavelength of $509.8 \mathrm{~nm}$ ) -0.07 (days from planting) -25.40 $(\mathrm{NDVI})+19.25$. Leaf reflectance was able to accurately predict $88.9 \%$ of the observations with a cutoff of 0.48 and a model of 173.40 (reflectance at $410 \mathrm{~nm})-34.74(\mathrm{NDVI})$ - 33.51 (reflectance at $743 \mathrm{~nm})+15.43$. The area under the receiver operator curve was best for leaf reflectance $(c=0.95)$ but also very high for canopy reflectance $(c=0.93)$ (Fig. 3). The majority of the asymptomatic observations were classified as healthy with $92 \%$ of asymptomatic observations classified as healthy by the leaf reflectance model and $87 \%$ by the canopy reflectance model. Predictions from the leaf reflectance model were subset by location and sampling time (Table 6). The greatest accuracy of the model was observed in August with a gradual decline in accuracy through the remainder of the season as nitrogen levels declined and plants entered senescence. 


\section{DISCUSSION}

In the absence of rhizomania or other diseases, the degree of yellowing of a field is negatively correlated with leaf nitrogen content and positively correlated with extractable sucrose (46), enabling predictions of yield. When rhizomania is present, it is difficult to distinguish between yellowing due to nitrogen deficiency in healthy beets or disease. In our study, leaves from symptomatic beets showed a reduction in nitrogen, chlorophyll, carotenoids, and betacyanins. Nitrogen levels showed a small but significant effect on chlorophyll and betacyanin levels but not carotenoids. Nitrogen is known to have a strong effect on chlorophyll levels, which in turn affects the concentration of accessory pigments (25). When chlorophyll, as measured by NDVI from leaf reflectance, was used as a covariate, significant differences between disease levels existed at three of seven sampling dates for CRI and two of seven sampling dates for RGR but never for ARI (data not shown). While the reduced chlorophyll in symptomatic beet leaves can be attributed to the reduced nitrogen, our data suggests that carotenoid and betacyanin levels are impacted by rhizomania independently of the nitrogen reduction.

The effects of chlorophyll dominated the logistic regression models developed for canopy and leaf reflectance. Since canopy reflectance is dominated by the effects of chlorophyll this is not surprising (41). NDVI is commonly used as a surrogate for chlorophyll content (14) and reflectance at $410 \mathrm{~nm}$ is also dominated by chlorophyll absorbance (16). Reflectance around $509.8 \mathrm{~nm}$ can be attributed to both chlorophyll and carotenoid content (18) with slight influences from red pigments such as anthocyanins and betacyanins (17; A. A. Gitelson, personal communication). Reflectance at $743 \mathrm{~nm}$ is controlled by leaf structure and is not related to any pigments (26). While betacyanins and carotenoids showed significant differences between healthy and symptomatic beets, the differences were not large enough to be selected by the stepwise algorithm of logistic regression except for the selection of the band at $509.8 \mathrm{~nm}$ for canopy reflectance. When the predictions from the leaf reflectance model were subset by sampling date and location, classification was most accurate in August, which is shortly after symptoms began appearing and before nitrogen began to be reduced, but classification was still acceptable up to harvest.

Vegetative indices showed significant differences, and the models developed from this dataset performed well in differentiating healthy and symptomatic beets throughout the growing season even in the presence of nitrogen deficiency. The narrow wavelengths measured for leaf reflectance allowed the use of a number of indices that could not be applied to larger bands of the CropScan field radiometer and provided a better tool for this initial study. Use of the integrating sphere provided leaf spectra without the impact of canopy architecture or soil background and with uniform lighting conditions. Canopy reflectance is impacted by reflectance from soil, variations in canopy architecture, and shadowing of leaves.

This study was designed to look for spectral differences between healthy and diseased beets with decreasing levels of nitrogen as the season progressed. The presence of asymptomatic beets presented a problem by reducing the number of observations of healthy beets. It is unknown how yield is impacted in these asymptomatic beets, though Truscott and Gilligan (42) have suggested they are an important source of inoculum for future years. We hypothesize that these asymptomatic beets were only recently infected, and disease symptoms did not have time to develop. If this is correct, these beets will likely have very low sugar content as the virus interferes with the conversion of carbohydrates to sucrose. Asymptomatic beets were more prominent in the southern region of Minnesota where BNYVV has been observed longer. This study was aimed at testing the feasibility of detecting disease in the presence of an abiotic stress with similar symptoms. To this end, the sampling strategy was biased to select obviously healthy and obviously diseased sugar beets. This is the first study of this kind on sugar beets, and therefore necessitated this biased approach. Future work will be needed to validate these findings for canopy reflectance with greater variability in nitrogen levels before this method will be ready for adoption by the sugar beet industry. Understanding the impact of disease on levels of pigments will assist in future studies of this disease.

\section{ACKNOWLEDGMENTS}

This work was supported in part by the Minnesota and North Dakota Sugar Beet Research and Education Board and the Texas Precision Agriculture Legislative Initiative. We would like to thank D. Major for technical assistance; Resource 21 for loan of the ASD radiometer and the integrating sphere; and F. Workneh for assistance with statistics and critical review of the manuscript.

\section{LITERATURE CITED}

1. Aparicio, N., Villegas, D., Casadesus, J., Araus, J. L., and Royo, C. 2000. Spectral vegetation indices as nondestructive tools for determining durum wheat yield. Agron. J. 92:83-91.

2. Ayanru, D. K. G., and Sharma, V. C. 1982. Effects of cassava mosaic disease on certain leaf parameters of field-grown cassava clones. Phytopathology 72:1057-1059.

3. Baret, F., Champion, I., Guyot, G., and Podaire, A. 1987. Monitoring wheat canopies with a high spectral resolution radiometer. Remote Sens. Environ. 22:367-378.

4. Bellairs, S. M., Turner, N. C., Hick, P. T., and Smith, R. C. G. 1996. Plant and soil influences on estimating biomass of wheat in plant breeding plots using field spectral radiometers. Aust. J. Agric. Res. 47:1017-1034.

5. Blackmer, T. M., Schepers, J. S., Varvel, G. E., and Walter-Shea, E. A. 1996. Nitrogen deficiency detection using reflected shortwave radiation from irrigated corn canopies. Agron. J. 88:1-5.

6. Blazquez, C. H., and Edwards, G. J. 1986. Spectral reflectance of healthy and diseased watermelon leaves. Ann. Appl. Biol. 108:243-249.

7. Brakke, M. K., White, J. L., Samson, R. G., and Joshi, J. 1988. Chlorophyll, chloroplast ribosomal RNA, and DNA are reduced by barley stripe mosaic virus systemic infection. Phytopathology 78:570-574.

8. Broge, N. H., and Leblanc, E. 2000. Comparing prediction power and stability of broadband and hyperspectral vegetation indices for estimation of green leaf area index and canopy chlorophyll density. Remote Sens. Environ. 76:156-172.

9. Burcky, K., and Beiss, U. 1986. Damage of sugarbeet caused by beet necrotic yellow vein virus (BNYVV) depending on the degree of soil infestation. II. Nutrient content and juice quality. Zuckerind. 111:11111118.

10. Burcky, K., Beiss, U., Winner, C., Drath, L., and Schiweck, H. 1978. Tests on the significance of nutrient supply for sugarbeet quality. II. Nitrogen and potassium [chemical quality, physical properties]. Zuckerind. 103:190-200.

11. Chang, C.-J. 1998. Pathogenicity of aster yellows phytoplasma and Spiroplasma citri on periwinkle. Phytopathology 88:1347-1350.

12. Daughtry, C. S. T., Walthall, C. L., Kim, M. S., Brown de Colstoun, E., and McMurtrey, J. E., III. 2000. Estimating corn leaf chlorophyll concentration from leaf and canopy reflectance. Remote Sens. Environ. 74:229-239.

13. Everitt, J. H., Escobar, D. E., Appel, D. N., Riggs, W. G., and Davis, M. R. 1999. Using airborne digital imagery for detecting oak wilt disease. Plant Dis. 83:502-505.

14. Gamon, J. A., and Surfus, J. S. 1999. Assessing leaf pigment content and activity with a reflectometer. New Phytol. 143:105-117.

15. Gitelson, A. A., Kaufman, Y. J., Stark, R., and Rundquist, D. 2002. Novel algorithms for remote estimation of vegetation fraction. Remote Sens. Environ. 80:76-87.

16. Gitelson, A. A., and Merzlyak, M. N. 1997. Remote estimation of chlorophyll content in higher plant leaves. Int. J. Remote Sens. 18:26912697.

17. Gitelson, A. A., Merzlyak, M. N., and Chivkunova, O. B. 2001. Optical properties and nondestructive estimation of anthocyanin content in plant leaves. J. Photochem. Photobiol. 74:38-45.

18. Gitelson, A. A., Zur, Y., Chivkunova, O. B., and Merzlyak, M. N. 2002. Assessing carotenoid content in plant leaves with reflectance spectroscopy. J. Photochem. Photobiol. 75:272-281.

19. Hatfield, J. L., and Pinter, P. J., Jr. 1993. Remote sensing for crop 
protection. Crop. Prot. 12:403-413.

20. Heidel, G. B., and Rush, C. M. 1994. Distribution of beet necrotic yellow vein virus, beet distortion mosaic virus, and an unnamed soilborne sugar beet virus in Texas and New Mexico. Plant Dis. 78:603-606.

21. Hosmer, D. W., and Lemeshow, S. 2000. Model-building strategies and methods for logistic regression. Pages 116-118 in: Applied Logistic Regression. 2nd ed. John Wiley and Sons, Inc., New York.

22. Jackson, R. D. 1986. Remote sensing of biotic and abiotic plant stress. Annu. Rev. Phytopathol. 24:265-287.

23. Kobayashi, T., Kanda, E., Kitada, K., Ishiguro, K., and Torigoe, Y. 2001. Detection of rice panicle blast with multispectral radiometer and the potential of using airborne multispectral scanners. Phytopathology 91:316323.

24. Lichtenthaler, H. K. 1987. Chlorophylls and carotenoids: Pigments of photosynthetic biomembranes. Methods Enzymol. 148:350-382.

25. Lopez-Cantarero, I., Lorente, F. A., and Romero, L. 1994. Are chlorophylls good indicators of nitrogen and phosphorus levels? J. Plant Nutr. 17:979-990.

26. Maas, S. J., and Dunlap, J. R. 1989. Reflectance, transmittance, and absorptance of light by normal, etiolated, and albino corn leaves. Agron. J. 81:105-110.

27. Mariotti, M., Ercoli, L., and Massoni, A. 1996. Spectral properties of irondeficient corn and sunflower leaves. Remote Sens. Environ. 58:282-288.

28. McGrath, M. T., and Pennypacker, S. P. 1990. Alteration of physiological processes in wheat flag leaves caused by stem rust and leaf rust. Phytopathology 80:677-686.

29. Milton, N. M., Eiswerth, B. A., and Ager, C. M. 1991. Effect of phosphorous deficiency on spectral reflectance and morphology of soybean plants. Remote Sens. Environ. 36:121-127.

30. Muller, H. J. 1983. The effect of virus on sugar beet physiology. Also the effect of previous crops on Rhizomania. Zuckerind. 108:760-763.

31. Nilsson, H.-E. 1991. Hand-held radiometry and IR-thermography of plant diseases in field plot experiments. Int. J. Remote Sens. 12:545-557.

32. Nilsson, H.-E. 1995. Remote sensing and image analysis in plant pathology. Annu. Rev. Phytopathol. 15:489-527.

33. Nilsson, H.-E., and Johnson, L. 1996. Hand-held radiometry of barley infected by barley stripe disease in a field experiment. Z. Pflanzenkr. Pflanzenschutz. 103:517-526.

34. Nutter, F. W. J., Guan, J., Gotlieb, A. R., Rhodes, L. H., Grau, C. R., and
Sulc, R. M. 2002. Quantifying alfalfa yield losses caused by foliar diseases in Iowa, Ohio, Wisconsin, and Vermont. Plant Dis. 86:269-277.

35. Raab, T. K., and Terry, N. 1994. Nitrogen source regulation of growth and photosynthesis in Beta vulgaris L. Plant Physiol. 105:1159-1166.

36. Raikes, C., and Burpee, L. L. 1998. Use of multispectral radiometry for assessment of Rhizoctonia blight in creeping bentgrass. Phytopathology 88:446-449.

37. Riedell, W. E., and Blackmer, T. M. 1999. Leaf reflectance spectra of cereal aphid-damaged wheat. Crop Sci. 39:1835-1840.

38. Rush, C. M., and Heidel, G. B. 1995. Furovirus diseases of sugar beets in the United States. Plant Dis. 79:868-875.

39. Schepers, J. S., Blackmer, T. M., Wilhelm, W. W., and Resende, M. 1996. Transmittance and reflectance measurements of corn leaves from plants with different nitrogen and water supply. J. Plant Physiol. 148:523-529.

40. Sziraki, I., Mustardy, L. A., Faludi Daniel, A., and Kiraly, Z. 1984. Alterations in chloroplast ultrastructure and chlorophyll content in rustinfected pinto beans at different stages of disease development. Phytopathology 74:77-84

41. Thomas, J. R., and Gausman, H. W. 1977. Leaf reflectance vs. leaf chlorophyll and carotenoid concentration for eight crops. Agron. J. 69:799-802.

42. Truscott, J. E., and Gilligan, C. A. 2001. The effect of cultivation on the size, shape, and persistence of disease patches in fields. Proc. Natl. Acad. Sci. 98:7128-7133.

43. Tuitert, G., and Hofmeester, Y. 1994. Epidemiology of beet necrotic yellow vein virus in sugar beet at different initial inoculum levels in the presence or absence of irrigation. Eur. J. Plant Pathol. 100:19-53.

44. Ulrich, A., Moraghan, J. T., and Whitney, E. D. 1993. Sugar beet. Pages 91-98 in: Nutrient Deficiencies \& Toxicities in Crop Plants. W. F. Bennett, ed. The American Phytopathological Society, St. Paul, MN.

45. Wiegand, C. L., Richardson, A. J., Escobar, D. E., and Gerbermann, A. H. 1991. Vegetation indices in crop assessments. Remote Sens. Environ. 35:105-119.

46. Winter, S. R. 1998. Sugarbeet response to residual and applied nitrogen in Texas. J. Sugar Beet Res. 35:43-62.

47. Zuckerman, E., Eshel, A., and Eyal, Z. 1997. Physiological aspects related to tolerance of spring wheat cultivars to Septoria tritici blotch. Phytopathology 87:60-65. 